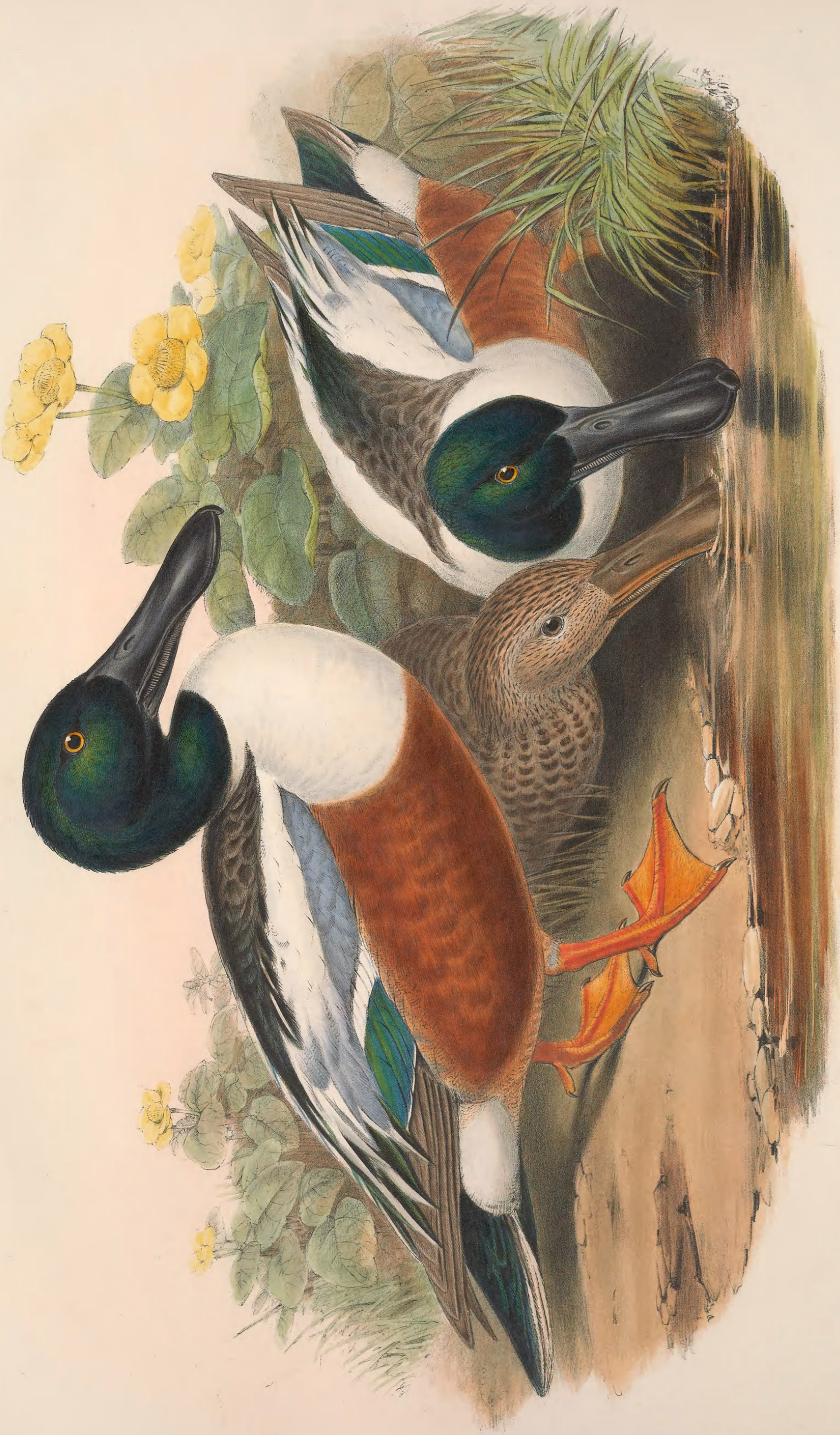

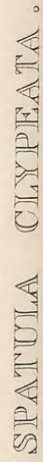




\section{SPATULA CLYPEATA.}

\section{Shoveller Duck.}

Anas clypeata, Linn. Faun. Suec., p. 42.

- rubens, Gmel. edit. Linn. Syst. Nat., tom. i. p. 519.

Spatula clypeata, Boie, Isis, 1822, p. 564.

Rhynchaspis clypeata, Steph. Cont. of Shaw's Gen. Zool., vol, xii. p. 115, pl. 48

Spathulea clypeata, Flem. Hist. of Brit. Anim., p. 123.

Clypeata macrorhynchus, Brehm, Vög. Deutschl., p. 876.

platyrhynchus, Brehm, ibid., p. 877.

pomarina, Brehm, ibid., p. 878 .

brachyrhynchus, Brehm, ibid., p. 879.

Although not very numerous at any time either in England, Scotland, or Ireland, we have abundant evidence of the occurrence of the Shoveller Duck, both in summer and winter, in all the three countries. It is especially partial to meres, ponds, and shallow waters, such as are seen in Holland, Belgium, and elsewhere, and, in India, to tanks and reservoirs; indeed it appears to have an instinctive knowledge of countries, however distant, that are subject to heavy rains, as an evidence of which, I may mention that I saw our Shoveller in the southern parts of Australia during the rainy season of 1839, when nearly the whole of the grassy flats were covered with water, and shot at a pair that rose before me on the shallow lagoons at Segenoe, in New South Wales, but did not succeed in killing either. The late Mr. Coxen, of Yarrundi, obtained a fine male, the skin of which I examined, and am therefore certain as to the identity of the species ; unfortunately it was so much mutilated by rats a few days after, that it was not worth preserving, or I should have brought it with me on my return to England. Since that period I have never seen an Australian specimen, neither have I been favoured with a sight of one from Java or any of the adjacent islands; but that it does visit those important countries, and also Borneo and the Philippines, is more than probable, since it is a common bird in India and China, and, according to Temminck, is as numerous in Japan as it is in any portion of Europe, over the whole of which, except in the extreme north, it has been observed; it is also fonnd in Africa, and extends its range over the northern portions of America, specimens having been received by me from as far south as Guatemala; at the same time it appears to be less numerous in the New than it is in the Old World. By some of our earlier writers the Shoveller was regarded as a winter visitant only to our islands; but the following extracts from the works of more recent authorities will show that it very frequently breeds therein :-

Mr. Hewitson tells us that "Mr. John Hancock has the nest and eggs of the Shoveller, which were found upon Prestwick Carr, a piece of waste ground of considerable extent near Newcastle-upon-Tyne, covered with heath and furze, boggy and intersected with drains, and having a piece of water near its centre. From thence, towards the end of May, a nest was brought to him containing nine eggs; it was composed of grass, mixed with the down of the bird, and was placed in the centre of a furze bush, by which it was sheltered. Two or three weeks after this a second nest was found, at a short distance from the spot from which the other had been taken : it was constructed of the same materials, was similarly situated, and contained ten eggs; these were quite fresh, and led to the supposition that they belonged to the same bird which had been previously deprived of its eggs.

"I have likewise received the eggs of the Shoveller from Norfolk, from Mr. Salmon, taken on the 10th of May from a nest which was placed amongst a quantity of green rushes, but without the profusion of feathers so generally observed in the nests of this tribe of birds, there being barely a sufficient quantity of dry grass to keep the eggs from the bare sand; it was much exposed, and contained eight eggs, which were within a few days of hatching.

“The Messrs. Paget state that the Shoveller is occasionally not at all uncommon in Norfolk, and that several nests, containing altogether fifty-six eggs, were found, during one summer, in Winterton Marshes.

"Mr. Charles St. John has found the eggs of this species on the banks of Loch Spynie, in Morayshire ; and Mr. Henry Milner tells me that it breeds on Hornsea Mere, in Yorkshire. The eggs differ considerably in size."

Further evidence of the bird's breeding in Norfolk is contained in the following note, obligingly forwarded to me by Lord Walsingham, from Merton Hall, Thetford, on the 24th of June, 1869 :- "You may, perhaps, care to know that not less than eight or ten pairs of Shovellers are in the habit of breeding here every year; this summer we gave away two sittings of eggs to a neighbour, who was anxions to rear some." 
That the bird also breeds in Dorsetshire is certain, two young birds which are in the collection of W. Thompson, Esq., of Weymouth, having been shot in the Frome river, a few miles below Dorchester, in July 1867 .

The Shoveller seldom, if ever, dives for its food ; neither does it ramble by night over the land far away from water. Its principal nourishment consists of aquatic grasses and other succulent plants, to which is probably added small freshwater mollusks, worms, and insects, for securing which its remarkably constructed bill is admirably adapted, the edges of both mandibles being thickly beset with fine pectinated laminæ, aptly compared by Wilson to a weaver's reed, by means of which the bird has the power of retaining any nutritive matters it may find, and of rejecting the mud and other substances not congenial to its stomach.

The Shoveller is subject to two very marked seasonal changes of plumage. During winter and spring its black bill, blue-green head, white breast, chestnut-coloured abdomen, blue shoulders, and black and white streaming tertiaries render him a very beautiful object, his beauty being greatly enhanced by his pale yellow pupils, seated like gems in the centre of his blue-green head; but, as soon as the female begins to incubate, those colours disappear, and, like the Mallard and the Teal, he assumes the more uniform brown colouring of the female; this garb is again thrown off in October or November, and the former one reassumed.

Mr. J. H. Gurney, Jun., has called my attention to a fact, which, indeed, had not escaped my notice, that some females are more red or chestnut-coloured on the abdomen than others, the reason of which is not well understood; it may be due to age, or to the normal change not having taken place. On reference to the accompanying Plate it will be seen that, ordinarily, the female, besides differing from her mate in having a mottled hrown garb, has the eyes brown and the bill olive, while the legs and feet are, like those of the male, of a fine orange-yellow.

As a tenant for the aviary or home ponds and lakes no bird is better adapted than the Shoveller, its disposition being as tame as its plumage is ornamental. When in good condition its flesh as a viand for the table is unsurpassed by that of any of the Duck tribe; indeed so much is it prized on this account, that authors on both sides of the Atlantic bear testimony to its excellence. Selby says "it is very delicate and well-flavoured, and, in consequence, highly esteemed ;" Wilson that it is uniformly juicy and well-tasted; and Audubon that "no sportsman who is a judge will ever pass by a Shoveller to shoot a Canvass-back," the excellent quality of whose flesh is proverbial. As an article of food it is therefore much sought after; and hundreds are sent from Holland to the London markets during every autumn and winter.

The Shoveller breeds in the central parts of marshy districts, the nest, which is placed on the ground, being usually formed in the tufts of coarse herbage abounding in such situations. The eggs are from ten to twelve in number, of a buffy white, with a faint tinge of green, and measure a trifle more than two inches in length by one inch and a half in breadth.

The young were formerly stated to be at first very shapeless and ugly, and the bill to be as broad as the body; but this was long since disproved by $\mathrm{Mr}$. Youell, in the thirteenth volume of the 'Transactions of the Linnean Society,' and by Yarrell, who says :- " That the bill of the young Shoveller, when hatched, is not dilated laterally, I can myself answer. During the summer of 1841 a pair of Shovellers made a nest and brought out their young on one of the islands in the Gardens of the Zoological Society. The bills of these ducklings were as narrow and the sides as parallel as the bills of some Gadwalls which were hatched at the same time on another island in the same piece of water."

The Plate represents two males and a female, of the natural size. The plant is the Marsh Marygold (Caltha palustris). 


\section{$2 \mathrm{BHL}$ Biodiversity Heritage Library}

Gould, John. 1873. "Shoveller Duck, Spatula clypeata [PI. 14]." The birds of Great Britain 5, -. https://doi.org/10.5962/p.324058.

View This Item Online: https://www.biodiversitylibrary.org/item/222497

DOI: https://doi.org/10.5962/p.324058

Permalink: https://www.biodiversitylibrary.org/partpdf/324058

\section{Holding Institution}

Smithsonian Libraries

\section{Sponsored by}

Biodiversity Heritage Library

\section{Copyright \& Reuse}

Copyright Status: Public domain. The BHL considers that this work is no longer under copyright protection.

This document was created from content at the Biodiversity Heritage Library, the world's largest open access digital library for biodiversity literature and archives. Visit BHL at https://www.biodiversitylibrary.org. 